\title{
Effects of 6-Cyano-7-nitroquinoxaline-2,3- dione on Nicotinic Receptor Subunit Transcript Expression in the Rat Brain
}

\author{
ROBERT E. MCCULLUMSMITH,* MICHELLE J. SEMINS, AND JAMES H. MEADOR-WOODRUFF \\ Department of Psychiatry and Mental Health Research Institute, University of Michigan Medical School, \\ Ann Arbor, Michigan 48109
}

\begin{abstract}
KEY WORDS CNQX; AMPA; kainate; mRNA; nicotinic cholinergic receptor; hippocampus; septum; medial habenula

ABSTRACT The nicotinic cholinergic system exerts potent modulatory effects on glutamatergic neurotransmission, an effect mediated in part by increased glutamate release following activation of presynaptic nicotinic cholinergic receptors. Ionotropic glutamate receptor agonists also stimulate release of acetylcholine, suggesting that these neurotransmitter systems reciprocally regulate one another. We investigated an interface between the nicotinic cholinergic and glutamatergic systems by measuring nicotinic receptor subunit transcript expression following administration of 6-cyano-7nitroquinoxaline-2,3-dione (CNQX), an antagonist of the AMPA and kainate subtypes of glutamate receptors. Using $\left[{ }^{35} \mathrm{~S}\right]$ in situ hybridization, we measured expression of $\alpha 2, \alpha 3$, $\alpha 4, \alpha 5, \alpha 7, \beta 2, \beta 3$, and $\beta 4$ nicotinic receptor subunit transcripts in the rat forebrain. Following 7 days of treatment with vehicle or CNQX ( $1 \mathrm{mg} / \mathrm{kg} / \mathrm{day}$ or $10 \mathrm{mg} / \mathrm{kg} / \mathrm{day})$, changes in nicotinic receptor subunit transcript expression were restricted to subunits that form heteromeric receptors. We found increased levels of transcripts for $\alpha 2$ and $\beta 2$ nicotinic receptor subunits in the hippocampus, decreased $\alpha 4$ subunit transcripts in the medial habenula and amygdala, and increased $\beta 2$ subunit transcripts in the septum and piriform cortex. We did not detect changes in expression of transcripts for the $\alpha 7$ subunit, which forms homomeric nicotinic receptors. Our findings indicate that expression of nicotinic cholinergic receptor subunit transcripts are regulated in a subunit- and region-specific fashion by CNQX, an antagonist of non-NMDA ionotropic glutamate receptors. Synapse 52:62-72, 2004. ๑ 2004 Wiley-Liss, Inc.
\end{abstract}

\section{INTRODUCTION}

Multiple studies have shown increased release of glutamate, GABA, and other neurotransmitters following presynaptic activation of nicotinic cholinergic receptors, contributing to a growing literature detailing the potent modulatory effects of the nicotinic cholinergic system (NCS) in the brain (McGehee et al., 1995; Lendvai et al., 1996; Alkondon et al., 1997; Aramakis and Metherate, 1998; Gioanni et al., 1999; Grillner and Svensson, 2000; Reuben et al., 2000; Alkondon and Albuquerque, 2001). The neuronal nicotinic cholinergic receptor (nAChR) is a ligand-gated ion channel abundantly expressed in cortical and subcortical structures (Itier and Bertrand, 2001). The native ligand for nAChRs, acetylcholine ( $\mathrm{ACh}$ ), is released from a relatively small number of cholinergic neurons that broadly innervate most areas of the brain (McGehee and Role, 1995; Dani, 2001). Nicotinic receptors are comprised of assemblies of subunits encoded by specific genes, $\alpha 2-\alpha 10$, and $\beta 2-\beta 4$ (Itier and Bertrand, 2001). These subunits can form either heteromeric $(\alpha 2-\alpha 6$, $\beta 2-\beta 4)$ or homomeric $(\alpha 7-\alpha 10)$ receptors (Picciotto et al., 2001). Several nicotinic receptors with specific combinations of subunits have been identified and characterized. The high-affinity $\left[{ }^{3} \mathrm{H}\right]$-nicotine binding site that accounts for $90 \%$ of the nicotinic sites in the brain is a pentamer comprised of obligate $\beta 2$ and $\alpha 4$ subunits in combination with $\alpha 5, \alpha 6, \beta 3$, and/or $\beta 4$ (Gotti et al., 1997; Court et al., 2000; Picciotto et al., 2001). Nicotinic receptors containing an $\alpha 3$ subunit are associated with

\footnotetext{
This work was supported by a Pfizer Postdoctoral Fellowship (R.E.M.) and MH53327 (J.H.M.W.)

*Correspondence to: Robert E. McCullumsmith, M.D., Ph.D., Mental Health Research Institute and Department of Psychiatry, University of Michigan, 205 Zina Pitcher Place, Ann Arbor, MI 48109-0720. E-mail: smithrob@umich.edu

Received 24 June 2003; Accepted 29 November 2003

DOI 10.1002/syn.20003
} 
binding to neuronal bungarotoxin. The $\alpha 7, \alpha 8$, and $\alpha 9$ subunits form pentameric homomers that bind $\alpha$-bungarotoxin. Neuronal nicotinic receptors permit calcium entry into the cell following binding by two ACh molecules to a site associated with the $\alpha$ subunits. Nicotinic receptors desensitize following exposure to agonist, an effect whose duration depends on receptor subunit composition (Itier and Bertrand, 2001; Picciotto et al., 2001). The high-affinity $\left[{ }^{3} \mathrm{H}\right]$-nicotine binding sites are highly expressed in the striatum and substantia nigra, with lower levels of expression in the neocortex and hippocampus (Court et al., 2000). Neuronal bungarotoxin sites are highly expressed in the hippocampus and neocortex, while $\alpha$-bungarotoxin sites are expressed in the hippocampus, midbrain, neocortex, and striatum (Court et al., 2000).

A number of studies have examined interactions between the nicotinic and glutamatergic neurotransmitter systems (Ramoa et al., 1990; Rasmusson et al., 1996; Shoaib et al., 1997). Administration of nicotine to slices of rat auditory cortex enhanced NMDA-receptor mediated excitatory postsynaptic potentials, while intracerebral microdialysis experiments demonstrated increased synaptic glutamate levels following application of nicotine (Aramakis and Metherate, 1998; Gioanni et al., 1999). Other work has demonstrated increased hippocampal ACh release following application of glutamate receptor agonists by retrograde microdialysis into the medial septum or the hippocampus (Moor et al., 1996). Similar effects on ACh release were reported in the striatum, suggesting that glutamate receptors can modulate activation of the NCS (Ikarashi et al., 1998; Knauber et al., 1999). These data suggest that the nicotinic cholinergic and glutamatergic neurotransmitter systems are integrated and reciprocally regulate one another.

Glutamatergic neurotransmission involves presynaptic release of glutamate, activation of pre- and

\section{Abbreviations}

$\begin{array}{ll}\text { ACh } & \text { acetylcholine } \\ \text { AMPA } & \alpha \text {-amino-3-hydroxy-5-methylisoxazole-4-propionic acid } \\ \text { AMY } & \text { amygdala } \\ \text { Cg } & \text { cingulate cortex } \\ \text { CNQX } & \text { 6-cyano-7-nitroquinoxaline-2,3-dione } \\ \text { DG } & \text { dentate gyrus } \\ \text { Fr } & \text { frontal cortex } \\ \text { GABA } & \text { gamma-aminobutyric acid } \\ \text { HT } & \text { hypothalamus } \\ \text { HPC } & \text { hippocampus } \\ \text { KA } & \text { kainate } \\ \text { MHN } & \text { medial habenula } \\ \text { nAChR } & \text { nicotinic cholinergic receptor } \\ \text { NCS } & \text { nicotinic cholinergic system } \\ \text { NMDA } & \text { N-methyl-D-aspartate } \\ \text { OT } & \text { olfactory tubercle } \\ \text { Par } & \text { parietal cortex } \\ \text { PCR } & \text { polymerase chain reaction } \\ \text { Pir } & \text { piriform cortex } \\ \text { SEP } & \text { septum } \\ \text { Te } & \text { temporal cortex } \\ \text { THA } & \text { thalamus } \\ \end{array}$

postsynaptic glutamate receptors, and tightly regulated reuptake of glutamate from the synaptic cleft (Danbolt, 2001). Glutamate receptor subtypes include three families of pharmacologically distinct ligandgated ion channels ( $N$-methyl-D-aspartate (NMDA), $\alpha$-amino-3-hydroxy-5-methylisoxazole-4-propionic acid (AMPA), and kainate (KA) receptors) as well as the G-protein-coupled metabotropic receptors (mGluR1mGluR8) (Nakanishi, 1992; Hollmann and Heinemann, 1994; Bleakman and Lodge, 1998). NMDA receptor-mediated depolarization of the postsynaptic neuron is preceded by localized depolarization via activation of AMPA receptors. This localized depolarization permits removal of $\mathrm{Mg}^{2+}$-mediated open channel blockade of NMDA receptors. The presynaptically localized KA receptors contribute to regulation of synaptic function by modulating neuronal glutamate release and astrocytic glutamate reuptake (Claudio et al., 2000; Delaney and Jahr, 2002).

The glutamate neurotransmitter system interacts with other neurotransmitters throughout the brain. Many of these interactions are mediated by the activities of AMPA and KA receptors. For example, AMPA receptor antagonists mediate region- and circuit-specific release of $\mathrm{ACh}$, dopamine, and serotonin, while activation of serotonin or dopamine receptor subtypes modulate AMPA receptor subunit expression (Naudon et al., 1992; Meador-Woodruff et al., 1996; Moor et al., 1996; Martin-Ruiz et al., 2001; Cai et al., 2002; Chao et al., 2002; Wu et al., 2002; Ghersi et al., 2003). The effects of AMPA and KA receptor modulation on expression of nicotinic receptor expression have not previously been reported. The purpose of this study was to investigate the modulatory effects of AMPA and KA receptors on the nicotinic cholinergic system. We utilized CNQX, an AMPA and KA receptor antagonist, to investigate the regulation of brain nicotinic receptor subunit transcript expression by the AMPA and KA receptors.

\section{MATERIALS AND METHODS Animals and tissue preparation}

Three groups of 10 adult, male Sprague-Dawley rats $(250 \mathrm{~g})$ were treated with daily subcutaneous injections of CNQX ( 1 or $10 \mathrm{mg} / \mathrm{kg}$ ) or vehicle (DMSO) for 7 days. These doses were selected based on previous studies that have demonstrated biochemical or behavioral changes following subchronic CNQX treatment (Healy and Meador-Woodruff, 1999; Mead and Stephens, 1999). Twenty-four hours after the last injection, brains from sacrificed animals were removed, rapidly frozen in isopentane $\left(-30^{\circ} \mathrm{C}\right)$, and stored at $-80^{\circ} \mathrm{C}$ until sectioned. Each brain was thawed for $30 \mathrm{~min}$ to a temperature of $-20^{\circ} \mathrm{C}$ and mounted for cryostat sectioning. Ten- $\mu \mathrm{m}$ sections were mounted on polylysinesubbed microscope slides, desiccated overnight at $4^{\circ} \mathrm{C}$, and stored at $-80^{\circ} \mathrm{C}$. 


\section{In situ hybridization}

Primers for polymerase chain reaction (PCR) amplification were designed for each cholinergic receptor subunit of interest using Primer3 (http://waldo.wi.mit. edu/c/s.dll/primer/primer3) and AMPLIFY (http:// www.wisc.edu/genetics/CATG/amplify/index.html; Bill Engels, Madison, WI). Unique areas of the rat $\alpha 2$ (GenBank accession \#L10077, coding region 1321-1718), $\alpha 3$ (X03440, 1223-1742), $\alpha 4$ (L31620, 1114-1642), $\alpha 5$ (NM_017978, 447-906), $\alpha 7$ (NM_012832, 125-624), $\beta 2$ (U42976, 147-562), $\beta 3$ (J04636, 1153-1632), and $\beta 4$ (L31622, 1251-1747) subunits were targeted for amplification from full-length rat clones of each subunit (generously provided by Dr. Daniel Goldman, University of Michigan, Ann Arbor, MI). Due to the occurrence of significant regions of homology between sequences for the $\alpha 2, \alpha 4$, and $\beta 2$ subunits, we performed two-way BLAST analysis of the full-length cDNAs to confirm that our probes were designed to specifically recognize their intended targets. Following amplification, DNA was extracted and purified with the QIAquick Gel Extraction Kit (Qiagen, Valencia, CA), subcloned using the Zero Blunt TOPO PCR Cloning Kit (Invitrogen, Carlsbad, CA), and sequenced (Thermo Sequenase Radiolabeled Termination Cycle Sequencing Kit, USB, Cleveland, $\mathrm{OH})$. For riboprobe synthesis, $10 \mu \mathrm{l}$ of $\left[{ }^{35} \mathrm{~S}\right]-$ UTP was dried and $2.0 \mu \mathrm{l} 5 \times$ transcription buffer, 1.0 $\mu \mathrm{l} 0.1 \mathrm{M}$ DTT, $1.0 \mu \mathrm{l}$ each of $10 \mathrm{mM}$ ATP, CTP, and GTP, $2.0 \mu l$ linearized plasmid DNA, $0.5 \mu l$ RNase inhibitor, and $1.5 \mu \mathrm{T}$ T3 or T7 RNA polymerase were combined and incubated for $2 \mathrm{~h}$ at $37^{\circ} \mathrm{C}$. Then $1.0 \mu \mathrm{l}$ DNase (RNase-free) was added and the mixture was incubated for $15 \mathrm{~min}$ at room temperature (RT). Radiolabeled probe was purified with microspin chromatography columns (Bio-Rad, Hercules, CA). Two slides per level for each probe were removed from $80^{\circ} \mathrm{C}$ and placed in 4\% (weight:vol) formaldehyde at RT for $1 \mathrm{~h}$. The slides were then washed in $2 \times \mathrm{SSC}(300 \mathrm{mM}$ $\mathrm{NaCl} / 30 \mathrm{mM}$ sodium citrate, $\mathrm{pH}$ 7.2) three times for 5 min each. Slides were washed in deionized water for 1 min and placed in $0.1 \mathrm{M}$ triethanolamine, $\mathrm{pH} 8.0$ / acetic anhydride, 400:1 (vol:vol) on a stir plate for $10 \mathrm{~min}$. A final wash was in $2 \times$ SSC for 5 min, followed by dehydration through graded alcohols and air-drying for 30 min. A coverslip with $30 \mu \mathrm{l}$ of riboprobe (1 million cpm, $75 \%$ formamide buffer (75\% formamide, $10 \%$ dextran sulfate, $3 \times \mathrm{SSC}, 50 \mathrm{mM} \mathrm{Na} \mathrm{HPO}_{4}(\mathrm{pH} 7.4), 10 \mathrm{mM}$ dithiothreitol, $1 \times$ Denhardt's solution, $100 \mu \mathrm{g} / \mathrm{ml}$ yeast tRNA), 0.01M DTT) was placed on each slide. Slides were placed in a covered tray with a filter paper liner saturated with $75 \%$ formamide. After overnight incubation at $55^{\circ} \mathrm{C}$, coverslips were removed and the slides were placed in $2 \times \mathrm{SSC}$ for $5 \mathrm{~min}$, followed by RNase $(200 \mu \mathrm{g} / \mathrm{ml}$ in $10 \mathrm{mM}$ Tris-HCl, $\mathrm{pH} 8.0 / 0.5 \mathrm{M} \mathrm{NaCl})$ at $37^{\circ} \mathrm{C}$ for $30 \mathrm{~min}$ and then washed as follows: $2 \times \mathrm{SSC}$ for $10 \mathrm{~min}$ at RT; $1 \times \mathrm{SSC}$ for $10 \mathrm{~min}$ at RT; $0.5 \times \mathrm{SSC}$ for $60 \mathrm{~min}$ at $55^{\circ} \mathrm{C}$; and $0.5 \times \mathrm{SSC}$ for $10 \mathrm{~min}$ at RT. The slides were dehydrated in graded ethanol solutions, air-dried, placed in X-ray cassettes, and apposed to Kodak XAR-5 film for 1-42 days, depending on the probe.

\section{Image and data analyses}

Film was developed and used for quantitative computer image analysis (NIH Image 1.61) as previously described (Meador-Woodruff et al., 1997). Tissue background readings were subtracted from duplicate leftand right-side gray scale values from specific regions of interest. Background-adjusted gray scale values were converted into optical density and subsequently averaged, providing one mean value per region per animal for each probe. Optical density values were converted to units of bound radiation from a standard curve generated from a $\left[{ }^{14} \mathrm{C}\right]$ microscale standard (Amersham Life Sciences, Buckinghamshire, UK) placed on each film (Williams, 1982; Downs and Williams, 1984). All data are expressed as nanocuries per gram of tissue $(\mathrm{nCi} / \mathrm{g})$. Statistical analyses were performed using analysis of variance and, when appropriate, post-hoc analyses were by Tukey's HSD; for all tests, $\alpha=0.05$.

\section{RESULTS \\ $\alpha 2$ Subunit expression and regulation}

$\alpha 2$ subunit transcripts were expressed in the dentate gyrus (DG) and throughout the hippocampal subfields (Fig. 1). In the HPC, we found a main effect for treatment $(\mathrm{F}(2,105)=74.9, P<0.0001)$ and region $(\mathrm{F}(4,105)=6.23, P<0.0001)$, but we did not find a treatment by region interaction (Fig. 2). Post-hoc analysis revealed increased $\alpha 2$ subunit transcript expression in the higher-dose CNQX treatment group vs. the lower-dose CNQX $(P=0.0001)$ and vehicle-treated groups $(P=0.0001)$ (Fig. 2). The lower dose CNQXtreated group was not significantly different from the vehicle-treated group. Significantly higher levels of $\alpha 2$ subunit transcripts were detected in the DG compared to the four hippocampal subfields (Fig. 2).

\section{a4 Subunit}

$\alpha 4$ subunit transcripts were differentially expressed in several areas of the rat brain, including the medial habenula and the amygdala (Fig. 3). In the HPC, we detected a main effect for region $(\mathrm{F}(4,95)=13.2, P<$ 0.0001 ), but not treatment or treatment by region interaction (Fig. 2). Significantly higher levels of $\alpha 4$ subunit transcripts were detected in the CA1 subfield vs. the other hippocampal subfields and DG (Fig. 2). We found a main effect for treatment in the medial habenula $(\mathrm{MHN})(\mathrm{F}(2,15)=8.56, P<0.003)$ and in the amygdala (AMY) $(\mathrm{F}(2,15)=7.32, P<0.006)$ (Fig. 4). Post-hoc analysis revealed significantly lower levels of $\alpha 4$ subunit transcripts in the MHN and AMY for both the higher $(P=0.019, P=0.009$, respectively) and 

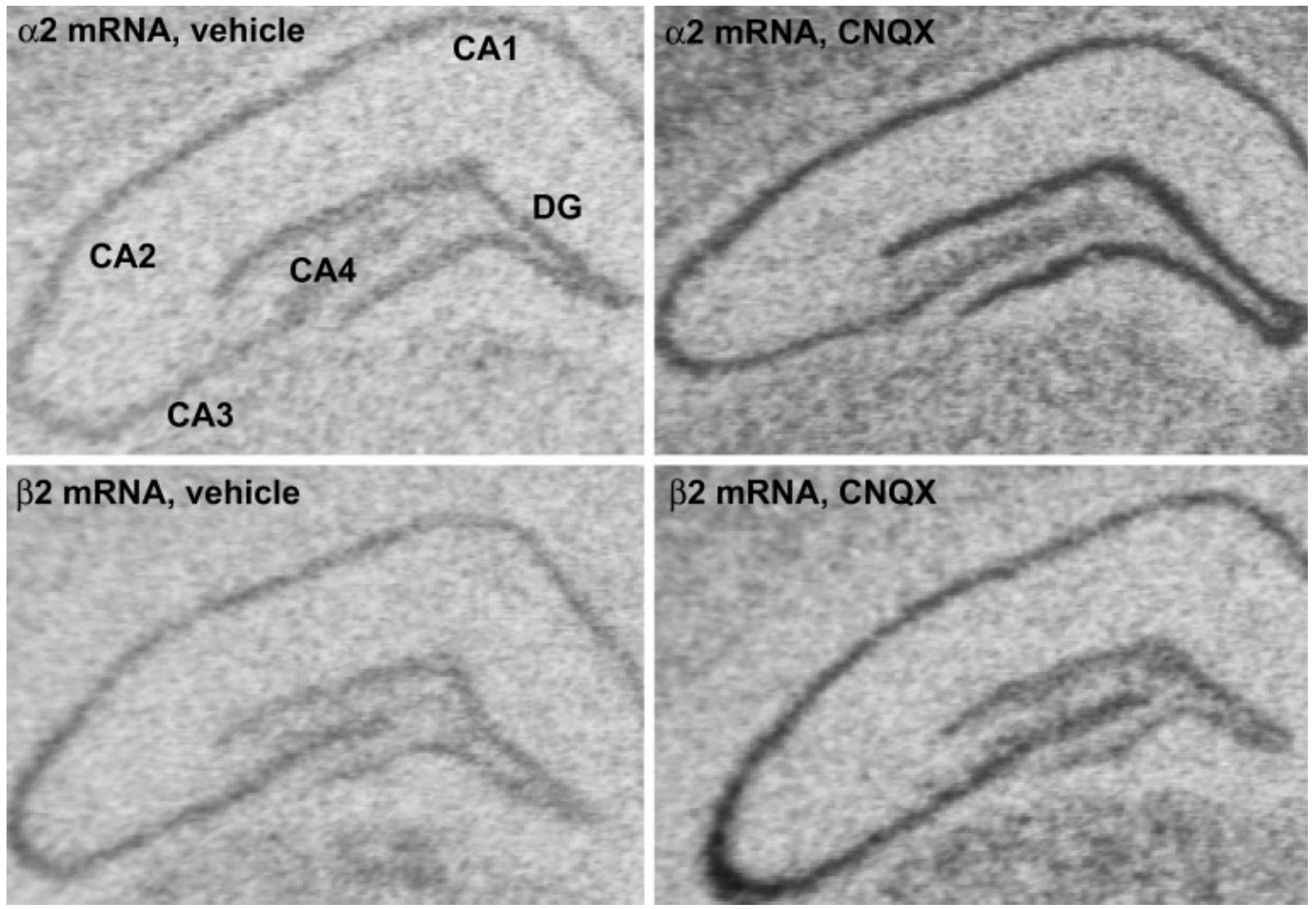

Fig. 1. In situ hybridization using $\left[{ }^{35} \mathrm{~S}\right]$-labeled antisense probes for the $\alpha 2$ and $\beta 2$ nicotinic receptor subunits in the dentate gyrus (DG) and hippocampal subfields CA1, CA2, CA3, and CA4 of rats treated for 1 week with vehicle or $10 \mathrm{mg} / \mathrm{kg} /$ day CNQX. Sections probed for $\alpha 2$ and $\beta 2$ were exposed to film for 42 and 9 days, respectively.

lower $(P=0.002, P=0.005)$ dose CNQX treatment groups vs. the control group (Fig. 4). We did not detect changes in $\alpha 4$ subunit transcript expression in the cingulate cortex $(\mathrm{Cg})$, parietal cortex (Par), thalamus (THA), hypothalamus (HT), frontal cortex (Fr), septum (SEP), HPC, or piriform cortex (Pir) (Fig. 4).

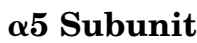

No treatment effects on $\alpha 5$ subunit mRNA expression were detected in the Fr, SEP, Cg, MHN, or temporal cortex (Te) (Fig. 5).

\section{$\alpha 7$ Subunit}

In the HPC, there was a main effect for region $(\mathrm{F}=$ 102.8, df 4, 105, $P<0.0001$ ), but not treatment, nor was there a treatment by region interaction (Fig. 2). Post-hoc analysis revealed significantly lower levels of mRNA expression in CA1 vs. the other CA subfields and the DG, as well as lower levels of expression in CA2 vs. CA3 and CA4, lower levels in CA3 vs. CA4, and higher levels in CA3 and CA4 vs. DG (Fig. 2). There were no treatment effects on $\alpha 7$ subunit mRNA expression in the THA, HT, AMY, Par, Cg, Pir, Fr, or SEP (Fig. 6).

\section{及2 Subunit}

The $\beta 2$ subunit mRNA was expressed in multiple regions of the rat brain, including the septum and piriform cortex (Fig. 7). In the HPC, we detected a main effect for CNQX treatment $(\mathrm{F}=20.3$, df 2, 105, $P<$ $0.0001)$ and region $(\mathrm{F}=22.8, \mathrm{df} 4,105, P<0.0001)$, but no treatment by region interaction (Figs. 1,2 ). Post-hoc analysis revealed significantly higher levels of mRNA expression in both the higher-dose $(P=0.0003)$ and lower-dose CNQX treatment groups $(P=0.0001)$ vs. the control group, and higher levels of mRNA expression in the higher-dose vs. lower-dose CNQX treatment group $(P=0.014)$. Post-hoc analysis for region revealed significantly lower levels of mRNA expression in CA1 vs. the other hippocampal subfields, lower levels of expression in DG vs. CA2, CA3, and CA4, and higher levels in CA3 vs. CA4 (Fig. 2). We also found a main effect for treatment in the SEP $(\mathrm{F}=3.63$, df $2,20, P=$ 0.045) and $\operatorname{Pir}(\mathrm{F}=10.8$, df $2,20, P=0.001)$ (Fig. 8). Post-hoc analysis revealed higher levels of $\beta 2$ subunit expression in the SEP $(P=0.035)$ for the higher-dose CNQX treatment group vs. the vehicle-treated group. Post-hoc analysis also revealed higher levels of expression in the Pir for the higher-dose CNQX treatment 

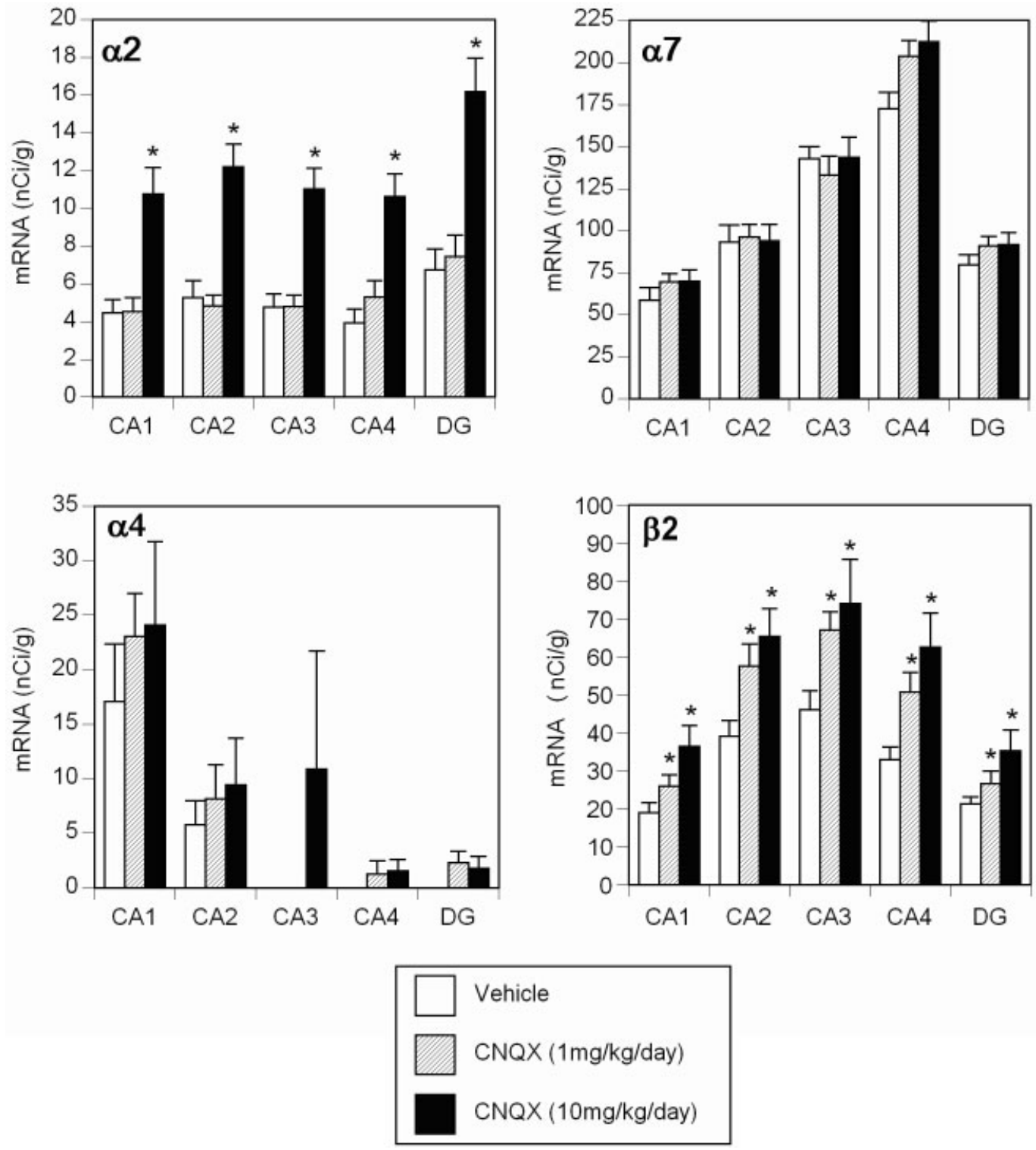

Fig. 2. $\alpha 2, \alpha 4, \alpha 7$, and $\beta 2$ nicotinic receptor subunit transcript expression in the dentate gyrus (DG) and hippocampal subfields following 7 days of CNQX treatment. Expression of $\alpha 2(10 \mathrm{mg} / \mathrm{kg} / \mathrm{day})$ and $\beta 2$ $(1 \mathrm{mg} / \mathrm{kg} /$ day and $10 \mathrm{mg} / \mathrm{kg} /$ day) transcripts in rats treated with CNQX was significantly elevated compared to the vehicle group. There were 10 rats in each treatment group. ${ }^{*} P<0.05$.

group vs. both the vehicle $(P=0.001)$ and lower-dose CNQX treatment groups $(P=0.013)$. We did not detect a treatment effect in the Fr, olfactory tubercle (OT), MHN, Cg, Par, THA, HT, or AMY (Fig. 8).

\section{$\alpha 3, \beta 3$, and $\beta 4$ Subunits}

$\alpha 3, \beta 3$, and $\beta 4$ subunit transcripts were restricted to the MHN. We did not detect an alteration in any of these subunit transcripts following CNQX treatment (Fig. 9).

\section{DISCUSSION}

In the present study we detected differential regulation of nicotinic cholinergic receptor subunit transcripts fol- lowing treatment with the AMPA and the kainate receptor antagonist CNQX (Table I). We found elevated levels of $\beta 2$ subunit transcripts in the HPC, SEP, and Pir, decreased levels of $\alpha 4$ subunit transcripts in the AMY and MHN, and increased levels of $\alpha 2$ subunit mRNA in the HPC (Table I). Our findings suggest that gene expression of nAChR subunits can be regulated by non-NMDA ionotropic glutamate receptors in a subunit- and regionspecific fashion. These changes in nAChR subunit expression likely reflect alterations of subunit stoichiometry of the nAChRs. Since the nAChRs have distinct functional characteristics based on their subunit composition, alterations in subunit expression affect nAChR activity in the synapse. 

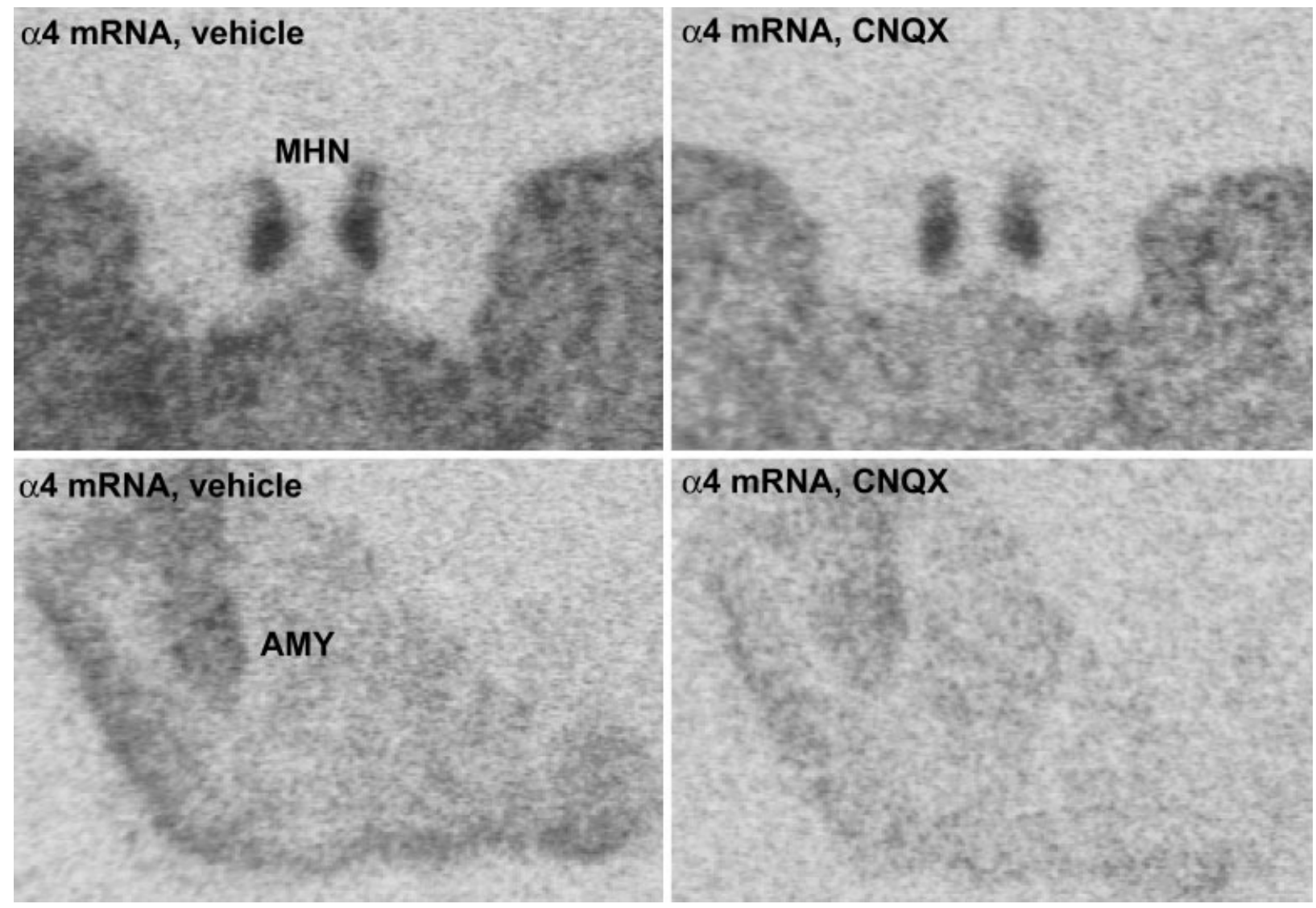

Fig. 3. In situ hybridization using $\left[{ }^{35} \mathrm{~S}\right]$-labeled antisense probes for the $\alpha 4$ nicotinic receptor subunit in the medial habenula (MHN) and amygdala (AMY) of rats treated for 1 week with vehicle or 10 $\mathrm{mg} / \mathrm{kg} /$ day CNQX. Sections probed for $\alpha 4$ were exposed to film for 6 days.

Numerous studies have demonstrated enhanced release of glutamate following activation of presynaptic nAChRs, a process likely mediated by direct calcium influx or localized depolarization and activation of voltage-dependent channels (McGehee et al., 1995; Aramakis and Metherate, 1998; Gioanni et al., 1999). nAChR-mediated calcium influx activates protein kinases and phosphatases, modifying synaptic functions such as neurotransmitter release (McGehee et al., 1995; Drew and Werling, 2001). Interestingly, our data suggest that the interface of the NCS and glutamatergic neurotransmission is not limited to nAChR-mediated neurotransmitter release. We found alterations in $\alpha 2, \alpha 4$, and $\beta 2 \mathrm{nAChR}$ subunit transcript expression following treatment with CNQX, suggesting that AMPA and KA receptor activity may directly participate in the modulation of $\mathrm{nAChR}$ function by regulating the expression of nAChR subunit genes.

There are several mechanisms that could account for glutamatergic regulation of nAChR expression. Expression of axon-terminal nAChRs acting as autoreceptors could be affected by antagonism of somatodendritic AMPA receptors coexpressed on cholinergic neurons (Kumamoto and Murata, 1995; Dani, 2001). Alternatively, expression of subunits that comprise postsynaptic high affinity (fast) nAChRs may be altered secondary to diminished synaptic ACh levels, since AMPA-mediated hippocampal ACh release can be blocked by CNQX treatment (Moor et al., 1996). Other possible mechanisms include an indirect CNQX-mediated decrease in glutamatergic tone in neuronal circuits that include cells expressing nAChRs. This is supported by reports that ACh becomes the primary excitatory neurotransmitter in the absence of glutamate excitation in primary hypothalamic neuronal cultures (Belousov et al., 2001, 2002). Interestingly, we detected increased expression of the obligate $\beta 2$ subunit transcripts in the HPC, SEP, and Pir, a finding consistent with past observations of augmented nicotinic cholinergic function following attenuation of glutamatergic activity by CNQX (Belousov et al., 2001, 2002).

Following treatment with CNQX, we detected increased levels of $\alpha 2$ transcripts in the HPC, increased $\beta 2$ transcripts in the HPC, SEP, and Pir, and decreased $\alpha 4$ transcripts in the MHN and AMY. In contrast, we did not detect changes in $\alpha 7$ mRNA expression in the HPC, AMY, Pir, or SEP with CNQX treatment. The $\alpha 7$ nicotinic subunit exclusively participates in the formation of a homomeric receptor, while $\alpha 2, \alpha 4, \beta 2$, and 


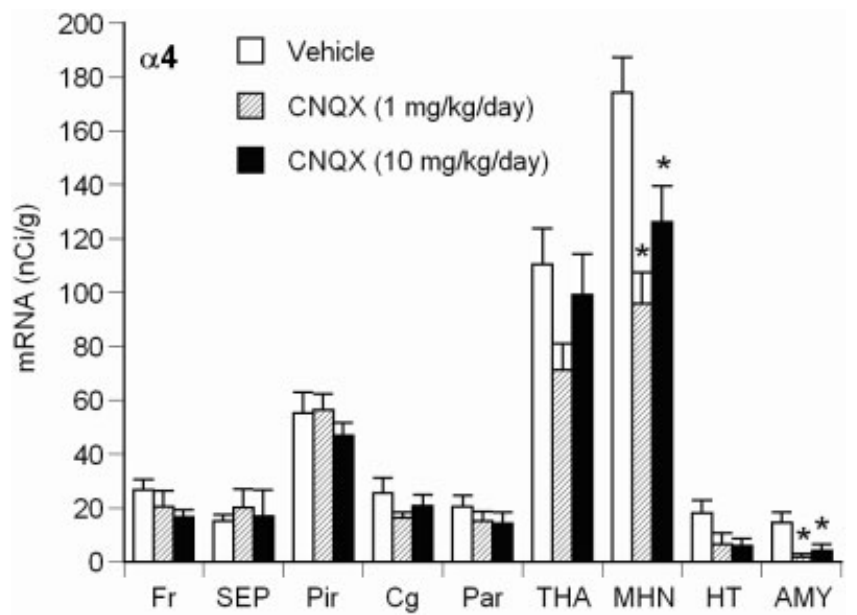

Fig. 4. $\alpha 4$ nicotinic receptor subunit transcript expression in the frontal cortex (Fr), septum (SEP), piriform cortex (Pir), cingulate cortex $(\mathrm{Cg})$, parietal cortex (Par), thalamus (THA), medial habenula (MHN), hypothalamus (HT), and amygdala (AMY) following 7 days of CNQX treatment. Expression of $\alpha 4$ transcripts in rats treated with 1 $\mathrm{mg} / \mathrm{kg} /$ day and $10 \mathrm{mg} / \mathrm{kg} /$ day CNQX was significantly decreased in the MHN and in the AMY compared to the vehicle group. There were 10 rats in each treatment group. ${ }^{*} P<0.05$.

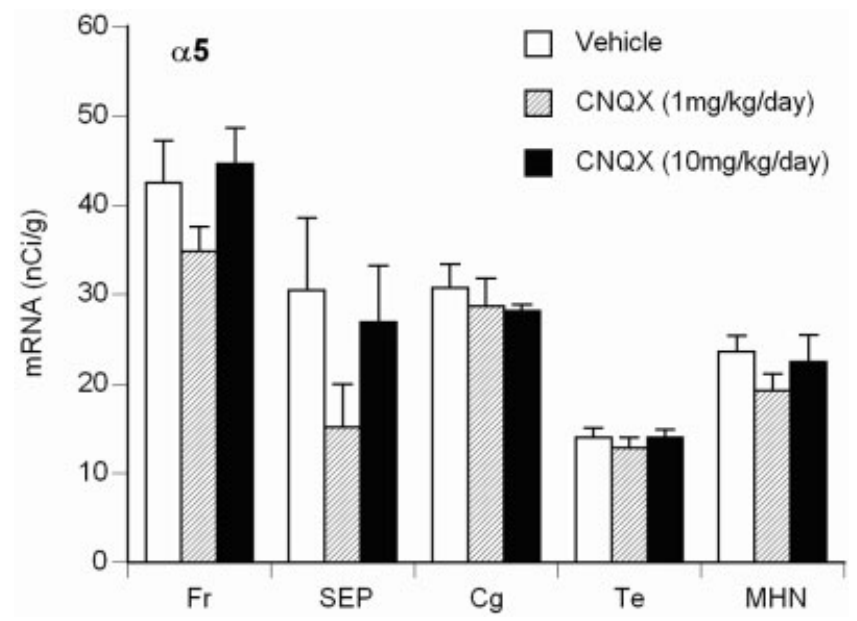

Fig. 5. $\alpha 5$ nicotinic receptor subunit transcript expression in the frontal cortex $(\mathrm{Fr})$, septum (SEP), cingulate cortex $(\mathrm{Cg})$, temporal cortex (Te), and medial habenula (MHN) following 7 days of CNQX treatment. Expression of $\alpha 5$ transcripts did not differ between CNQXand vehicle-treated groups. There were 10 rats in each treatment group.

other subunits contribute to the formation of heteromeric nicotinic receptor subtypes (Itier and Bertrand, 2001; Picciotto et al., 2001). Thus, our findings suggest that inhibition of KA and/or AMPA receptors only affects expression of a subset of pharmacologically distinct nAChRs. Several studies have demonstrated electrophysiological differences between heteromeric $(\alpha 4 \beta 2)$ and homomeric $(\alpha 7)$ nAChRs in the rat hippocampus. $\alpha 7$ selective ligands had no effect on excitatory postsynaptic current (EPSC), while $\alpha 3 \beta 2$-specific compounds, or low concentrations of nicotine itself, modulate EPSCs in hippocampal slices, suggesting a

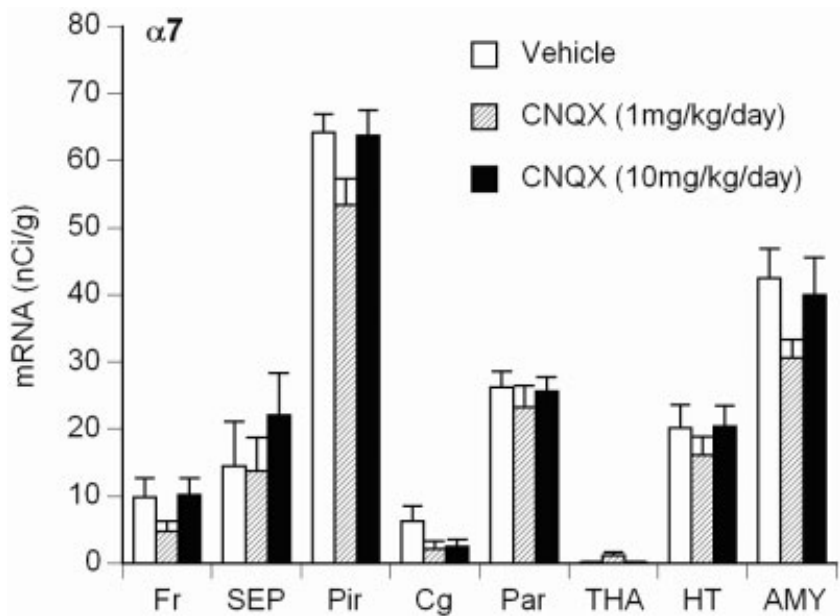

Fig. 6. $\alpha 7$ nicotinic receptor subunit transcript expression in the frontal cortex (Fr), septum (SEP), piriform cortex (Pir), cingulate cortex $(\mathrm{Cg})$, parietal cortex (Par), thalamus (THA), hypothalamus (HT), and amygdala (AMY) following 7 days of CNQX treatment. Expression of $\alpha 7$ transcripts did not differ between CNQX- and vehicle-treated groups. There were 10 rats in each treatment group.

non- $\alpha 7$ mechanism (Alkondon and Albuquerque, 2002). In a related study, mediation of inhibition of CA1 pyramidal neurons was three times stronger by $\alpha 4 \beta 2$ vs. $\alpha 7$ receptors. (Alkondon and Albuquerque, 2001). Differences between heteromeric and homomeric nAChRs are not limited to the HPC. The $\alpha 4 \beta 2$ antagonist dihydro- $\beta$-erythrodine $(\mathrm{DH} \beta \mathrm{E})$ attenuated the excitatory effects of nicotine on dopaminergic neurons in the ventral tegmental area, while the $\alpha 7$ antagonist methyllycaconitine (MLA) did not (Grillner and Svensson, 2000).

The differences in neurophysiological function between heteromeric and homomeric nAChRs may underlie discrete behavioral tasks. For example, Levin et al. (2002) evaluated the effects on specific memory tasks of antagonism of $\alpha 4 \beta 2$ vs. $\alpha 7$ containing nAChRs in the rat. Reference memory was impaired following administration of the $\alpha 7$ antagonist MLA by cannula in the HPC, but not the $\alpha 4 \beta 2$ antagonist DH $\beta \mathrm{E}$ (Felix and Levin, 1997; Levin et al., 2002). In contrast, working memory was impaired following administration of either MLA or $\mathrm{DH} \beta \mathrm{E}$, suggesting that some cognitive functions involve differential activation of nAChR subtypes. The discrete functional roles of the $\alpha 7$ and $\alpha 4 \beta 2$ nAChRs in the HPC are consistent with our findings of differential nAChR transcript expression following CNQX treatment, and support our hypothesis that expression of phenotypically distinct nicotinic receptor subtypes is differentially regulated by CNQX, a modulator of non-NMDA ionotropic glutamate receptors.

We detected increased $\alpha 2$ and $\beta 2$ subunit transcript expression in the HPC following treatment with CNQX, suggesting either an increase in nicotinic receptors containing these subunits or an alteration in receptor stoichiometry. In addition, we did not detect 

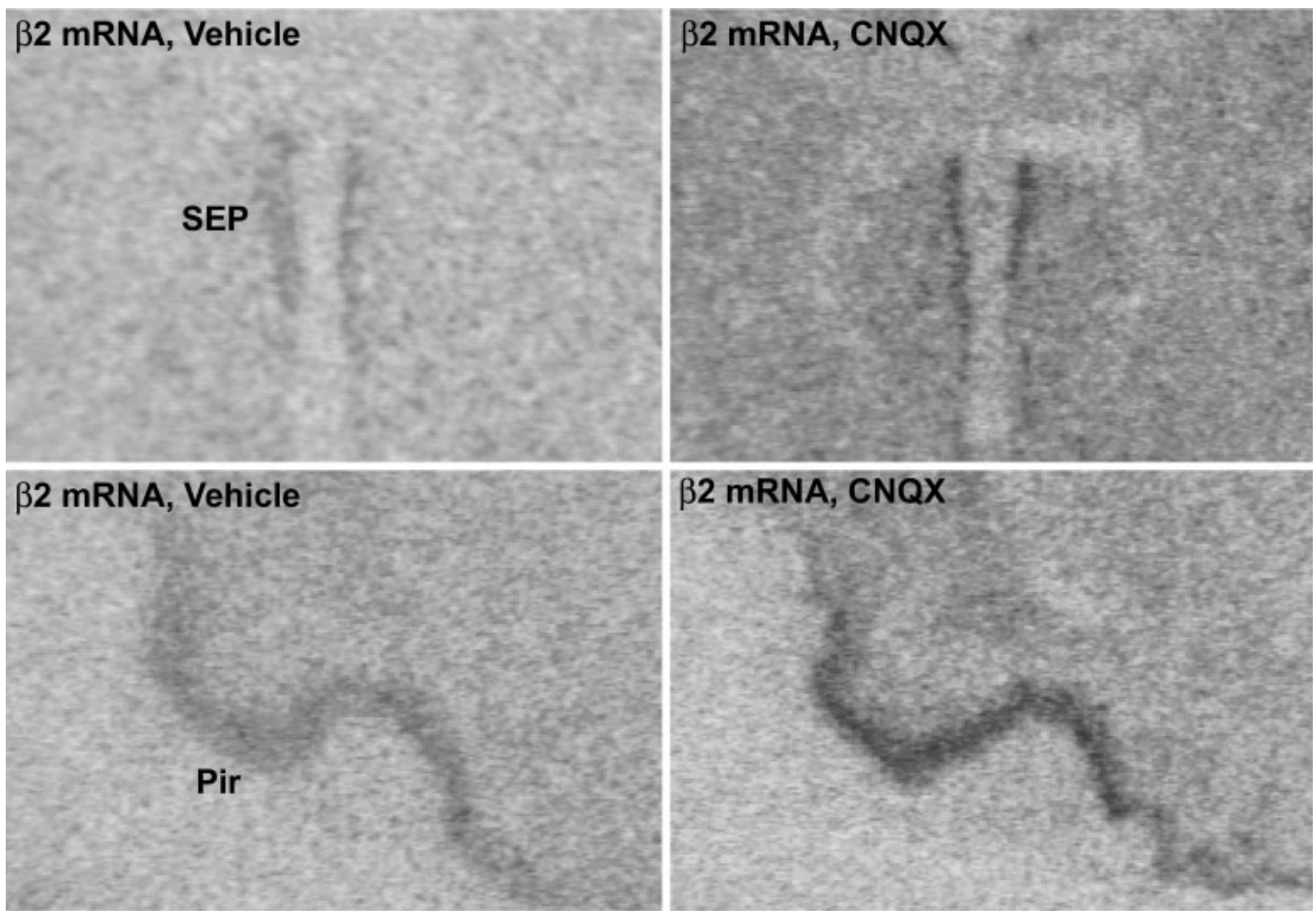

Fig. 7. In situ hybridization using $\left.{ }^{35} \mathrm{~S}\right]$-labeled antisense probes for the $\beta 2$ nicotinic receptor subunit in the septum (SEP) and piriform cortex (Pir) of rats treated for 1 week with vehicle or $10 \mathrm{mg} / \mathrm{kg} / \mathrm{day}$ CNQX. Sections probed for $\beta 2$ were exposed to film for 9 days.

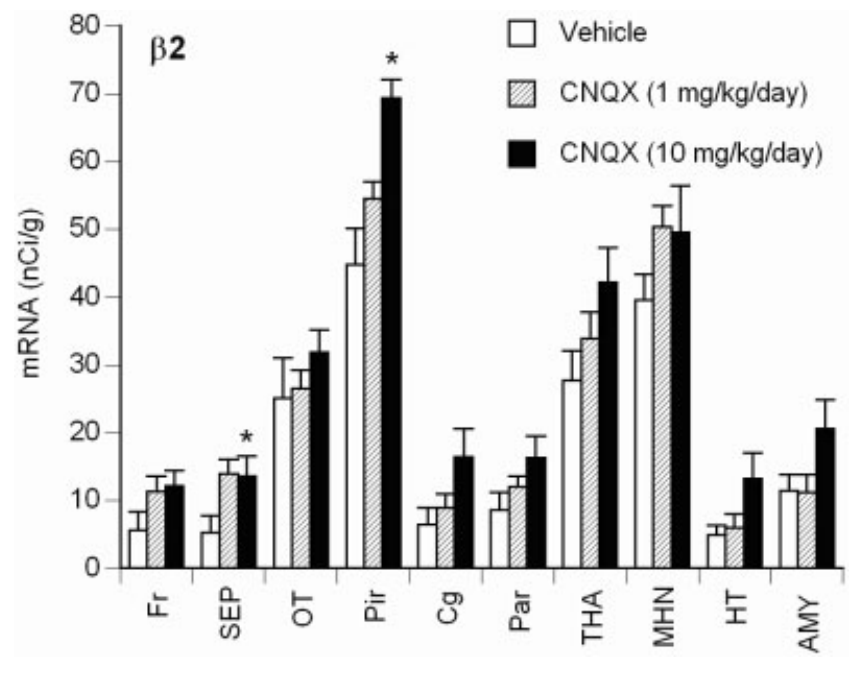

Fig. 8. $\quad \beta 2$ nicotinic receptor subunit transcript expression in the frontal cortex (Fr), septum (SEP), olfactory tubercle (OT), piriform cortex (Pir), cingulate cortex $(\mathrm{Cg})$, parietal cortex (Par), thalamus (THA), medial habenula (MHN), hypothalamus (HT), and amygdala (AMY) following 7 days of CNQX treatment. Expression of $\beta 2$ transcripts in rats treated with $10 \mathrm{mg} / \mathrm{kg} /$ day CNQX was significantly increased in the SEP and in the Pir compared to the vehicle group. There were 10 rats in each treatment group. ${ }^{*} P<0.05$. changes in $\alpha 4$ subunit mRNA levels, suggesting that alterations in nAChR expression following CNQX treatment are limited to a subset of heteromeric receptor subunits. In the HPC, expression of $\alpha 2, \alpha 3$, and $\alpha 4$ subunits has been correlated with medium, fast, and slow peak rise times, respectively, measured by whole cell recordings of interneurons in the stratum oriens and stratum radiatum of the HPC (Sudweeks and Yakel, 2000). The authors of that study suggested that $\alpha 2$-containing receptors were both a major component of the total nAChR population in the stratum oriens and functionally distinct from $\alpha 3$ - or $\alpha 4$-containing receptors (Sudweeks and Yakel, 2000). Thus, an increase in hippocampal $\alpha 2$ subunit expression, regulated indirectly by CNQX via modulation of AMPA and KA receptor activity, may lead to a change in nAChR-mediated currents.

We detected decreased $\alpha 4$ subunit transcript expression in the AMY following treatment with CNQX, suggesting an interaction with the glutamatergic system in this region. $\alpha 4$ knockout mice have been used to investigate the contributions of the $\alpha 4$ subunit to nicotinic receptor function (Marubio and Changeux, 2000). High-affinity nicotine binding was significantly attenuated in $\alpha 4$ knockout mice, confirming that this 
subunit is central for generation of type $2(\alpha 4 \beta 2)$ nicotinic currents in many brain areas. $\alpha 4$ knockouts also displayed a decrease in antinociception, an effect localized to the raphe magnus and the thalamus based on patch clamp recordings (Marubio and Changeux, 2000). Other work suggests that the NCS contributes to performance of both passive avoidance and water maze testing via circuitry that involves both the amygdala and the nucleus basalis, while implantation of nicotinic receptor-modulating compounds in the AMY decreased FSH release (Piva et al., 1980; Riekkinen et al., 1993).

Administration of CNQX also decreased $\alpha 4$ subunit mRNA expression in the MHN. The MHN links the limbic forebrain with diencephalic structures and mediates diverse neurophysiological functions, including sensory gating, reward pathways, and stereotyped motor behaviors (Ellison, 1994). One study demonstrated that heteromeric nAChRs accounted for $75 \%$ of nicotine-induced currents in the medial MHN, a population that may include $\alpha 4$-containing receptors (Quick et al., 1999). Interestingly, amphetamine and cocaine induced degeneration of neurons in the lateral MHN, while a different study demonstrated that administra-

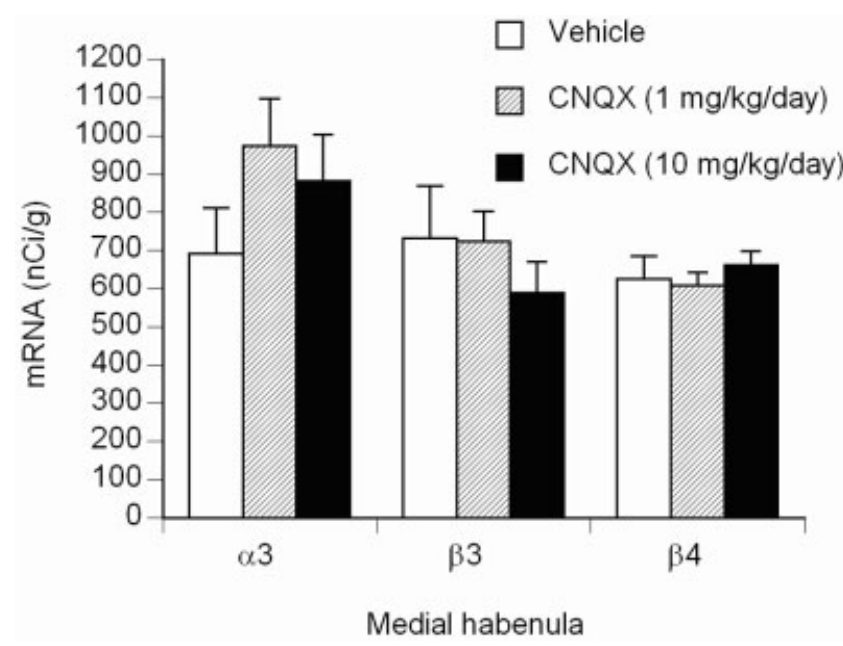

Fig. 9. $\alpha 3, \beta 3$, and $\beta 4$ nicotinic receptor subunit transcript expression in the medial habenula (MHN) following 7 days of CNQX treatment. Expression of these transcripts did not differ between CNQXand vehicle-treated groups. There were 10 rats in each treatment group. tion of high levels of nicotine tartrate led to neurotoxicity in the medial MHN (Carlson et al., 2001; Ellison, 2002). In both of these studies, neuropathologic changes were observed in the fasciculus retroflexus, an output tract of the MHN. These studies implicate the NCS in the MHN as a possible substrate for stimulantmediated pathophysiology. Our data suggest a direct interface between the glutamatergic and nicotinic cholinergic systems in the MHN.

Increases in $\beta 2$ subunit transcript expression in the SEP following CNQX treatment may be explained by previous work that has demonstrated expression of NMDA, AMPA, and KA receptors on cholinergic neurons in the SEP (Kumamoto and Murata, 1995). Attenuation of AMPA receptor activation with CNQX would decrease NMDA receptor activation, decreasing calcium influx, altering intracellular signaling pathways, and generation of excitatory postsynaptic currents. Interestingly, administration of CNQX by microdialysis into the medial septum decreased ACh release, suggesting that increased $\beta 2$ subunit expression is secondary to diminished release of ACh (Moor et al., 1996). However, 7 days of intravenous administration of the nAChR agonists nicotine and/or mecamylamine did not alter $\beta 2$ mRNA expression in the SEP, suggesting that regulation of subunit expression involves more than an alteration in the synaptic level of neurotransmitter or agonist (Pauly et al., 1996).

While expression of subunits that comprise both hetero- and homomeric nAChRs has been demonstrated in the Pir, we only detected changes in $\beta 2$ transcript expression in this region (Wada et al., 1989). To our knowledge, the interface of the glutamatergic and nicotinic cholinergic systems in the Pir has not previously been examined. In the Pir, ACh release enhanced longterm potentiation, likely contributing to associative memory function (Barkai and Hasselmo, 1997; Patil et al., 1998; Linster and Hasselmo, 2001). More work is needed to assess the relevance of increased $\beta 2$ subunit expression in the Pir following CNQX treatment.

A limitation of this study is that we only measured nAChR subunit transcript expression. For example, while we did not detect a change in $\alpha 7$ subunit mRNA expression, there may have been a change in $\alpha 7$ subunit translation or $\alpha 7$ receptor mobilization to the cell

TABLE I. Summary of changes in nicotinic receptor subunit expression following treatment with CNQX

\begin{tabular}{|c|c|c|c|c|c|c|c|c|c|c|c|c|c|}
\hline Region & & HPC & $\mathrm{Fr}$ & SEP & Pir & $\mathrm{Cg}$ & Par & THA & MHN & $\mathrm{HT}$ & AMY & $\mathrm{Te}$ & $\mathrm{OT}$ \\
\hline \multirow{4}{*}{$\begin{array}{l}\text { Heteromeric } \alpha \\
\text { subunits }\end{array}$} & $\alpha 2$ & $\uparrow$ & - & - & - & - & - & - & - & - & - & - & - \\
\hline & $\alpha 3$ & - & - & - & - & - & - & - & - & - & - & - & - \\
\hline & $\alpha 4$ & nc & nc & nc & nc & nc & nc & nc & $\downarrow$ & nc & $\downarrow$ & - & - \\
\hline & $\alpha 5$ & - & nc & nc & - & nc & - & - & nc & - & - & nc & - \\
\hline \multirow{3}{*}{$\begin{array}{l}\text { Heteromeric } \beta \\
\text { subunits }\end{array}$} & $\beta 2$ & $\uparrow$ & nc & $\uparrow$ & $\uparrow$ & nc & nc & nc & nc & nc & nc & - & nc \\
\hline & $\beta 3$ & - & - & - & - & - & - & - & nc & - & - & - & - \\
\hline & $\beta 4$ & - & - & - & - & - & - & - & nc & - & - & - & - \\
\hline Homomeric subunit & $\alpha 7$ & nc & nc & nc & nc & nc & nc & nc & - & nc & nc & - & - \\
\hline
\end{tabular}

Abbrieviations: increased $(\uparrow)$ or decreased $(\downarrow)$ transcript expression, no change detected (nc), not measured (-), amygdala (AMY), cingulate cortex (Cg), 6-cyano-7-nitroquinoxaline-2,3-dione (CNQX), hypothalamus (HT), hippocampus (HPC), medial habenula (MHN), olfactory tubercle (OT), parietal cortex (Par), piriform cortex (Pir), frontal cortex (Fr), septum (SEP), temporal cortex (Te), thalamus (THA). 
surface following CNQX treatment. Furthermore, an alteration in transcript expression does not necessarily indicate an alteration in expression of functional receptors. Despite these limitations, our findings may be conservatively interpreted to indicate an important interaction between these excitatory neurotransmitter systems.

This study demonstrates alterations in nAChR subunit transcript expression following treatment with CNQX, an AMPA and KA receptor antagonist, suggesting a regulatory interface between the nicotinic cholinergic and glutamatergic neurotransmitter systems. Changes in transcript expression were confined to a subset of $\mathrm{nAChR}$ subunits associated with heteromeric receptor channels, supporting the hypothesis that expression of phenotypically distinct nicotinic receptor subtypes is differentially regulated by CNQX via modulation of non-NMDA ionotropic glutamate receptors.

\section{ACKNOWLEDGMENT}

We thank Daniel Healy, M.D., for assistance in this study.

\section{REFERENCES}

Alkondon M, Albuquerque EX. 2001. Nicotinic acetylcholine receptor alpha7 and alpha4beta2 subtypes differentially control GABAergic input to CA1 neurons in rat hippocampus. J Neurophysiol 86:30433055 .

Alkondon M, Albuquerque EX. 2002. A non-alpha7 nicotinic acetylcholine receptor modulates excitatory input to hippocampal CA1 interneurons. J Neurophysiol 87:1651-1654.

Alkondon M, Pereira EF, Barbosa CT, Albuquerque EX. 1997. Neuronal nicotinic acetylcholine receptor activation modulates gammaaminobutyric acid release from CA1 neurons of rat hippocampal slices. J Pharmacol Exp Ther 283:1396-1411.

Aramakis VB, Metherate R. 1998. Nicotine selectively enhances NMDA receptor-mediated synaptic transmission during postnatal development in sensory neocortex. J Neurosci 18:8485-8495.

Barkai E, Hasselmo MH. 1997. Acetylcholine and associative memory in the piriform cortex. Mol Neurobiol 15:17-29.

Belousov AB, O'Hara BF, Denisova JV. 2001. Acetylcholine becomes the major excitatory neurotransmitter in the hypothalamus in vitro in the absence of glutamate excitation. J Neurosci 21:2015-2027.

Belousov AB, Hunt ND, Raju RP, Denisova JV. 2002. Calcium-dependent regulation of cholinergic cell phenotype in the hypothalamus in vitro. J Neurophysiol 88:1352-1362.

Bleakman D, Lodge D. 1998. Neuropharmacology of AMPA and kainate receptors. Neuropharmacology 37:1187-1204.

Cai X, Gu Z, Zhong P, Ren Y, Yan Z. 2002. Serotonin 5-HT1A receptors regulate AMPA receptor channels through inhibiting $\mathrm{Ca} 2+/$ calmodulin-dependent kinase II in prefrontal cortical pyramidal neurons. J Biol Chem 277:36553-36562.

Carlson J, Noguchi K, Ellison G. 2001. Nicotine produces selective degeneration in the medial habenula and fasciculus retroflexus. Brain Res 906:127-134.

Chao SZ, Ariano MA, Peterson DA, Wolf ME. 2002. D1 dopamine receptor stimulation increases GluR1 surface expression in nucleus accumbens neurons. J Neurochem 83:704-712.

Claudio OI, Ferchmin P, Velisek L, Sperber EF, Moshe SL, Ortiz JG. 2000 . Plasticity of excitatory amino acid transporters in experimental epilepsy. Epilepsia 41(Suppl 6):S104-110.

Court JA, Martin-Ruiz C, Graham A, Perry E. 2000. Nicotinic receptors in human brain: topography and pathology. J Chem Neuroanat 20:281-298.

Danbolt NC. 2001. Glutamate uptake. Prog Neurobiol 65:1-105.

Dani JA. 2001. Overview of nicotinic receptors and their roles in the central nervous system. Biol Psychiatry 49:166-174.

Delaney AJ, Jahr CE. 2002. Kainate receptors differentially regulate release at two parallel fiber synapses. Neuron 36:475-482.
Downs AM, Williams MA. 1984. An improved approach to the analysis of autoradiographs containing isolated sources of simple shape: method, theoretical basis and reference data. J Microsc 136:1-22.

Drew AE, Werling LL. 2001. Protein kinase C regulation of dopamine transporter initiated by nicotinic receptor activation in slices of rat prefrontal cortex. J Neurochem 77:839-848.

Ellison G. 1994. Stimulant-induced psychosis, the dopamine theory of schizophrenia, and the habenula. Brain Res Brain Res Rev 19:223239.

Ellison G. 2002. Neural degeneration following chronic stimulant abuse reveals a weak link in brain, fasciculus retroflexus, implying the loss of forebrain control circuitry. Eur Neuropsychopharmacol $12: 287-297$

Felix R, Levin ED. 1997. Nicotinic antagonist administration into the ventral hippocampus and spatial working memory in rats. Neuroscience 81:1009-1017.

Ghersi C, Bonfanti A, Manzari B, Feligioni M, Raiteri M, Pittaluga A. 2003. Pharmacological heterogeneity of release-regulating presynaptic AMPA/kainate receptors in the rat brain: study with receptor antagonists. Neurochem Int 42:283-292.

Gioanni Y, Rougeot C, Clarke PB, Lepouse C, Thierry AM, Vidal C. 1999. Nicotinic receptors in the rat prefrontal cortex: increase in glutamate release and facilitation of mediodorsal thalamo-cortical transmission. Eur J Neurosci 11:18-30.

Gotti C, Fornasari D, Clementi F. 1997. Human neuronal nicotinic receptors. Prog Neurobiol 53:199-237.

Grillner P, Svensson TH. 2000. Nicotine-induced excitation of midbrain dopamine neurons in vitro involves ionotropic glutamate receptor activation. Synapse 38:1-9.

Healy DJ, Meador-Woodruff JH. 1999. Glutamatergic modulation of subcortical motor and limbic circuits. Ann NY Acad Sci 877:684687.

Hollmann M, Heinemann S. 1994. Cloned glutamate receptors. Annu Rev Neurosci 17:31-108.

Ikarashi Y, Yuzurihara M, Takahashi A, Ishimaru H, Shiobara T, Maruyama Y. 1998. Direct regulation of acetylcholine release by N-methyl-D-aspartic acid receptors in rat striatum. Brain Res 795: $215-220$.

Itier V, Bertrand D. 2001. Neuronal nicotinic receptors: from protein structure to function. FEBS Lett 504:118-125.

Knauber J, Kischka U, Roth M, Schmidt WJ, Hennerici M, Fassbender K. 1999. Modulation of striatal acetylcholine concentrations by NMDA and the competitive NMDA receptor-antagonist AP-5: an in vivo microdialysis study. $J$ Neural Transm 106:35-45.

Kumamoto E, Murata Y. 1995. Excitatory amino acid-induced currents in rat septal cholinergic neurons in culture. Neuroscience 69:477-493.

Lendvai B, Sershen H, Lajtha A, Santha E, Baranyi M, Vizi ES. 1996. Differential mechanisms involved in the effect of nicotinic agonists DMPP and lobeline to release [3H]5-HT from rat hippocampal slices. Neuropharmacology 35:1769-1777.

Levin ED, Bradley A, Addy N, Sigurani N. 2002. Hippocampal alpha 7 and alpha 4 beta 2 nicotinic receptors and working memory. Neuroscience 109:757-765.

Linster C, Hasselmo ME. 2001. Neuromodulation and the functional dynamics of piriform cortex. Chem Senses 26:585-594.

Martin-Ruiz R, Puig MV, Celada P, Shapiro DA, Roth BL, Mengod G, Artigas F. 2001. Control of serotonergic function in medial prefrontal cortex by serotonin-2A receptors through a glutamate-dependent mechanism. J Neurosci 21:9856-9866.

Marubio LM, Changeux J. 2000. Nicotinic acetylcholine receptor knockout mice as animal models for studying receptor function. Eur J Pharmacol 393:113-121.

McGehee DS, Role LW. 1995. Physiological diversity of nicotinic acetylcholine receptors expressed by vertebrate neurons. Annu Rev Physiol 57:521-546.

McGehee DS, Heath MJ, Gelber S, Devay P, Role LW. 1995. Nicotine enhancement of fast excitatory synaptic transmission in CNS by presynaptic receptors. Science 269:1692-1696.

Mead AN, Stephens DN. 1999. CNQX but not NBQX prevents expression of amphetamine-induced place preference conditioning: a role for the glycine site of the NMDA receptor, but not AMPA receptors. J Pharmacol Exp Ther 290:9-15.

Meador-Woodruff JH, King RE, Damask SP, Bovenkerk KA. 1996. Differential regulation of hippocampal AMPA and kainate receptor subunit expression by haloperidol and clozapine. Mol Psychiatry 1:41-53.

Meador-Woodruff JH, Haroutunian V, Powchik P, Davidson M, Davis KL, Watson SJ. 1997. Dopamine receptor transcript expression in striatum and prefrontal and occipital cortex. Focal abnormalities in orbitofrontal cortex in schizophrenia. Arch Gen Psychiatry 54:1089-1095. 
Moor E, Auth F, DeBoer P, Westerink BH. 1996. Septal and hippocampal glutamate receptors modulate the output of acetylcholine in hippocampus: a microdialysis study. J Neurochem 67:310-316.

Nakanishi S. 1992. Molecular diversity of glutamate receptors and implications for brain function. Science 258:597-603.

Naudon L, Leroux-Nicollet I, Costentin J. 1992. Consequences of an intrastriatal injection of kainic acid on the dopaminergic neuronal and vesicular uptake systems. Brain Res 593:32-38.

Patil MM, Linster C, Lubenov E, Hasselmo ME. 1998. Cholinergic agonist carbachol enables associative long-term potentiation in piriform cortex slices. J Neurophysiol 80:2467-2474.

Pauly JR, Marks MJ, Robinson SF, van de Kamp JL, Collins AC. 1996. Chronic nicotine and mecamylamine treatment increase brain nicotinic receptor binding without changing alpha 4 or beta 2 mRNA levels. J Pharmacol Exp Ther 278:361-369.

Picciotto MR, Caldarone BJ, Brunzell DH, Zachariou V, Stevens TR, King SL. 2001. Neuronal nicotinic acetylcholine receptor subunit knockout mice: physiological and behavioral phenotypes and possible clinical implications. Pharmacol Ther 92:89-108.

Piva F, Borrell J, Limonta P, Gavazzi G, Martini L. 1980. Cholinergic inputs to the amygdala and the control of gonadotrophin release. Acta Endocrinol (Copenh) 93:1-6.

Quick MW, Ceballos RM, Kasten M, McIntosh JM, Lester RA. 1999. Alpha3beta4 subunit-containing nicotinic receptors dominate function in rat medial habenula neurons. Neuropharmacology 38:769783.

Ramoa AS, Alkondon M, Aracava Y, Irons J, Lunt GG, Deshpande SS, Wonnacott S, Aronstam RS, Albuquerque EX. 1990. The anticonvulsant MK-801 interacts with peripheral and central nicotinic acetylcholine receptor ion channels. J Pharmacol Exp Ther 254:7182

Rasmusson DD, Szerb IC, Jordan JL. 1996. Differential effects of alpha-amino-3-hydroxy-5-methyl-4-isoxazole propionic acid and Nmethyl-D-aspartate receptor antagonists applied to the basal forebrain on cortical acetylcholine release and electroencephalogram desynchronization. Neuroscience 72:419-427.

Reuben M, Boye S, Clarke PB. 2000. Nicotinic receptors modulating somatodendritic and terminal dopamine release differ pharmacologically. Eur J Pharmacol 393:39-49.

Riekkinen Jr P, Riekkinen M, Sirvio J. 1993. Cholinergic drugs regulate passive avoidance performance via the amygdala. J Pharmacol Exp Ther 267:1484-1492.

Shoaib M, Schindler CW, Goldberg SR, Pauly JR. 1997. Behavioural and biochemical adaptations to nicotine in rats: influence of MK801, an NMDA receptor antagonist. Psychopharmacology (Berl) 134: $121-130$.

Sudweeks SN, Yakel JL. 2000. Functional and molecular characterization of neuronal nicotinic $\mathrm{ACh}$ receptors in rat CA1 hippocampal neurons. J Physiol 527(Pt 3):515-528.

Wada E, Wada K, Boulter J, Deneris E, Heinemann S, Patrick J, Swanson LW. 1989. Distribution of alpha 2, alpha 3, alpha 4, and beta 2 neuronal nicotinic receptor subunit mRNAs in the centra nervous system: a hybridization histochemical study in the rat. J Comp Neurol 284:314-335.

Williams MA. 1982. Autoradiography: its methodology at the present time. J Microsc 128:79-94.

Wu WR, Li N, Sorg BA. 2002. Regulation of medial prefrontal cortex dopamine by alpha-amino-3-hydroxy-5-methylisoxazole-4-propionate/kainate receptors. Neuroscience 114:507-516. 